\title{
Effects of Prosopis laevigata pods on carcass characteristics, non-carcass components, meat quality, fatty acid profile and sensory attributes
}

\author{
L.Y. Peña-Avelino', J. M. Pinos-Rodríguez ${ }^{2 \#}$, J. G. Vicente ${ }^{2}$, J. C. García-López ${ }^{3}$, L. Yáñez ${ }^{3}$ \& A. \\ Grajales $^{3}$ \\ ${ }^{1}$ Facultad de Medicina Veterinaria y Zootecnia, Universidad Autónoma de Tamaulipas, México \\ ${ }^{2}$ Facultad de Medicina Veterinaria y Zootecnia, Universidad Veracruzana, 91710, Veracruz, México \\ ${ }^{3}$ Instituto de Investigación de Zonas Desérticas, Facultad de Medicina, Facultad de Ciencias Químicas, Universidad \\ Autónoma de San Luis Potosí, México
}

(Received 17 April 2017; Accepted 18 August 2017; First published online 25 September 2017)

Copyright resides with the authors in terms of the Creative Commons Attribution 4.0 South African License.
See: http://creativecommons.org/licenses/by/4.0/za
Condition of use: The user may copy, distribute, transmit and adapt the work, but must recognize the authors and the South African
Journal of Animal Science.

\begin{abstract}
It was hypothesized that feeding mesquite pods to male Rambouillet lambs would have no negative effects on carcass characteristics, meat chemical composition and fatty acid composition of Longissimus thoracis et lumborum (LTL). Twenty-one male lambs ( 2.5 months old and $21 \pm 1.44 \mathrm{~kg}$ bodyweight) were randomly assigned to one of three experimental diets, two of which replaced maize grain and stover with mesquite pods (Prosopis laevigata) (PL): $0 \mathrm{~g} \mathrm{PL} / \mathrm{kg}$ feed (PL0), $250 \mathrm{~g} \mathrm{PL} / \mathrm{kg}$ feed (PL250) and $500 \mathrm{~g} \mathrm{PL} / \mathrm{kg}$ feed (dry matter basis). The feeding trial lasted 72 days. Carcass traits, chemical composition, fatty acid profile, and sensory characteristics of meat were measured. Carcass linear dimensions, non-carcass components, digestive tract and offal, compression value, and chemical composition of meat were similar in all treatments. Dietary inclusion of PL decreased carcass shrinkage loss. Lambs fed PL500 had better muscle conformation and degree of fat. Meat produced by PL-fed lambs was well accepted by panellists who judged meat appearance, colour, flavour, juiciness, toughness, and stringiness. In lambs fed PL0, the LTL muscle was lighter and yellower than that of animals fed PL250 and PL500 diets. Fatty acid composition was altered. The PLO diet resulted in lower percentages of total trans fatty acids (TFA) and saturated fatty acids (SFA) and higher percentages of most unsaturated fatty acids (UFA) and polyunsaturated fatty acids (PUFA) n-6 compared with PL250 and PL500 diets. Mesquite diets of up to $500 \mathrm{~g} / \mathrm{kg}$ dry matter (DM) for growing lambs improved carcass quality and nutritional parameters of the meat.
\end{abstract}

Keywords: Mesquite, muscle conformation, rumen content

\#Corresponding author: jpinos@uv.mx

\section{Introduction}

The major strategy for developing livestock industries in which production of grain is limited and cost is high should be to increase the use of low-cost indigenous feed resources to reduce the requirements for imported feed. Mesquite (Prosopis spp.) is a leguminous tree that grows in several arid and semi-arid regions of the world and provides feed biomass when grains and pasture reserves are low (Sawal et al., 2004). Mesquite pods contain $220 \mathrm{~g}$ free sugars, $78 \mathrm{~g}$ crude protein, $21 \mathrm{~g}$ fat, and a potential degradation of $163 \mathrm{~g} / \mathrm{kg}$ DM (Peña-Avelino et al., 2014) and can therefore be used to balance diets that are based on grain. Mesquite pods have been evaluated as a potential feed ingredient for livestock in many species, including sheep (Mahgoub et al., 2005a; Mahgoub et al., 2005b; Obeidat et al., 2008; Obeidat et al., 2011). Most of these studies have shown that mesquite pods could replace conventional feeds without causing health problems or affecting growth performance in lambs. In a preliminary study, mesquite $(P$. laevigata) pods replaced a third of conventional ingredients (grain, by-products or forage) in finishing lamb diets with no effect on growth performance (Negrete et al., 2016). On the contrary, the addition of $300 \mathrm{~g}$ pods $/ \mathrm{kg}$ DM reduced feed costs by $21 \%$, and improved carcass yield and proportion of UFA in subcutaneous fat. The inclusion of a high proportion of mesquite pods (500 g/ $/ \mathrm{kg} \mathrm{DM}$ ) in lamb fattening diets improved average daily gain, feed intake and feed conversion, because this feedstuff provided a good source of soluble carbohydrates and was of adequate particle size to improve rumen nitrogen $(\mathrm{N})$ metabolism (Peña-Avelino et al., 2016). High proportions of mesquite pods are safe for finishing lambs, but it is necessary to evaluate whether the effects of mesquite pods on performance and carcass characteristics affect meat characteristics 
such as nutritional value, fatty acid profile and sensory attributes. Therefore, the objective of this study was to evaluate the effects of replacing maize grain with high levels of mesquite pods on carcass and chemical characteristics, fatty acid and sensory evaluation of meat from finishing lambs.

\section{Materials and methods}

The experiment was approved by the Academic Committee of the Centro de Biociencias (Animal Ethics Certificate Number Abr15/004) of the Universidad Autónoma de San Luis Potosí, and was carried out in compliance with the regulations established by the Animal Protection Law enacted by the State of San Luis Potosi, Mexico. A comprehensive description of the design for this study and details of the lambs, experimental diets and feeding procedures are given in Peña-Avelino et al. (2016). Briefly, 21 non-castrated male Rambouillet lambs weaned at 2.5 months of age with $21 \pm 1.44 \mathrm{~kg}$ average initial bodyweight were used in the study. The animals were confined in individual pens $(1.2 \mathrm{~m} \times 0.8 \mathrm{~m})$ equipped with feeders and water troughs and randomly assigned to one of the three experimental treatments, consisting of three proportions of mesquite pods. Lambs were subjected to 12 days of adaptation to the experimental diets before the 72-day trial. Experimental diets included maize grain, soybean meal and corn stover (PL0) and PL-based diets consisting of $250 \mathrm{~g}$ (PL250) and $500 \mathrm{~g}$ (PL500) mesquite pods/ $\mathrm{kg}$ dry matter to replace equal amounts of maize. Diets averaged (per kg DM basis) $146 \mathrm{~g}$ crude protein, $226 \mathrm{~g}$ neutral detergent neutral, 34 $\mathrm{g}$ fat and $12 \mathrm{MJ}$ metabolizable energy (Peña- Avelino et al., 2016). Lambs had free access to feed and water, which were served twice a day (at 8:00 and 14:00 hours). The amount of feed offered and orts were recorded daily.

On day 73, after a 16-hour fasting period, all lambs were stunned with the captive bolt method and were slaughtered using standard procedures in a commercial slaughterhouse regulated by Mexican animal health law (NOM-033-SAG/ZOO-2014). Live weight was obtained before slaughter, and non-carcass components (heart, liver, spleen, kidney, testes, lungs, trachea, digestive tract and offal) were weighed immediately after slaughter. Carcass weight was recorded to determine hot carcass weight. The carcasses were refrigerated for 24 hours at $4{ }^{\circ} \mathrm{C}$ to obtain cold carcass weight, and refrigeration losses were calculated as carcass shrinkage loss. Hot carcass dressing and cold carcass dressing percentages were calculated by dividing hot carcass weight and cold carcass weight by final bodyweight and multiplying each result by 100 , as described by Zimerman et al. (2008). The carcasses were classified for conformation and fat using the EU scale (EEC Regulation 1278/94): E: excellent; U: very good; R: good; O: fair; P: poor. Following ColomerRocher et al. (1988) and Ruiz de Huidobro et al. (2005), the conformation scale was divided into three subclasses to produce a scale from 1 to 15 . Degree of fat cover was taken into account using a classification range from 1 to 5 (1: low, 2: slight, 3: average, 4: high, 5: very high). Kidney fat cover content was assessed with a scoring system that considers pelvic-renal fat as a whole (1: low, 2: average, 3: high). Subcutaneous fat thickness was measured using a digital calibrator (Mitutoyo, UK) $4 \mathrm{~cm}$ from the spinal column and at the level of the 13th rib. Carcass linear dimensions, as described by Ruiz de Huidobro et al. (2005), were taken as follows: L: internal carcass length (length from cranial edge of the symphysis pelvis to the cranial edge of the first rib), F: hind limb length (length from perineum to distal edge of the tarsus), B: buttock perimeter (maximum perimeter at G), G: buttock width (widest buttock measurement on a horizontal plane on the hanging carcass), Th: thorax depth (maximum distance between the sternum and the back of the carcass at the sixth thoracic vertebra), and $\mathrm{Wr}$ : thorax width (widest carcass measurement at the ribs). Carcass compactness indices were calculated from these carcass conformation measurements: $L / G, G / F, W r / T h$, $\mathrm{Th} / \mathrm{L}$ and $\mathrm{Th} / \mathrm{G}$.

A day after slaughter (after 24 hours' refrigeration), the LTLs of the left and right sides from T10 to L6 were sampled, refrigerated at $2{ }^{\circ} \mathrm{C}$ and transported for less than one hour to the laboratory. The left side of LTL was used for physical and chemical analysis, while the right side was used for sensory analysis. In the laboratory, $\mathrm{pH}_{24}$ was immediately measured ( 24 hours post mortem). For that, $3 \mathrm{~g}$ refrigerated LTL was homogenized with deionized water $(20 \mathrm{ml})$ using a blender (Waring 51BL32 700, Torrington, CT, USA). The $\mathrm{pH}_{24}$ of LTL samples was measured with a $\mathrm{pH}$ meter (Thermo-Orion 410Aplus, Torrington, CT, USA). The left and right sides of $L T L$ were vacuum packed and frozen at $-20^{\circ} \mathrm{C}$ until analysis.

Meat quality parameters (compression, colour and chemical composition) were measured on LTL muscle dissected from the left half of the carcass, which had been left to age for $48 \mathrm{~h}$ at $4{ }^{\circ} \mathrm{C}$. Three determinations were performed on each sample. Six parallelepipeds of approximately $1 \times 1 \times 2 \mathrm{~cm}$ (height $\times$ width $\times$ length) from each sample were cut parallel to the long axis of the muscle fibres. A compression test was carried out at room temperature $\left(20 \pm 2{ }^{\circ} \mathrm{C}\right)$, applying up to $20 \%$ strain at a speed of $50 \mathrm{~mm} / \mathrm{min}$, with a computer-controlled Instron universal texturometer model 3365 (Instron Engineering Corp., High Wycombe, UK), equipped with a modified compression cell that prevents transverse elongation of raw meat. Meat colour was read in the lab colour space with a colorimeter (Konica Minolta On Colour CM-2500d Online, Osaka, Japan): luminosity (Hunter $L^{*}$ value), redness (Hunter $a^{*}$ value), and yellowness (Hunter $b^{*}$ value). 
Subsamples of LTL were placed in a 100-mL beaker and freeze-dried using a Labconco freeze dryer (Model 4.5, Labconco Corp., Kansas City, MO, USA) until the total weight of the beaker and sample did not decrease by more than $0.1 \mathrm{~g}$ in 12 hours. Moisture percentage was calculated by loss in weight owing to freeze-drying. After moisture had been determined, the samples were mixed and powdered using a ceramic mortar. Samples were placed in jars and sealed to prevent them from regaining moisture. Fat percentages were determined with a fat extractor (Labconco Corp., Kansas City, MO, USA) using the method described by Camfield et al. (1997). Crude protein and ash content were determined following AOAC procedures (2006). To assess fatty acid composition, subsamples of LTL were homogenized according to Folch et al. (1957). The esterified samples were analysed using an Agilent Technologies gas chromatograph with flame ionization detection, following Gómez-Brandón et al. (2008).

For sensory analysis, the right side of frozen LTL was thawed and aged for 72 hours at a temperature of $4{ }^{\circ} \mathrm{C}$. After thawing, the LTL was trimmed for any external connective and fat tissue. Meat subsamples $(150 \mathrm{~g})$ were wrapped in aluminium foil and cooked at $200{ }^{\circ} \mathrm{C}$ until an internal temperature of $85^{\circ} \mathrm{C}$ was reached (Komprda et al., 2012). Cooked meat was cut into cubes (approx. $1 \mathrm{~cm}^{3}$ ), which were put on plates and allocated individually to a single glass. The panel consisted of 84 untrained consumers. Each panellist evaluated three meat samples, corresponding to each treatment. Thus, the total samples corresponding to 21 lambs were evaluated four times each. Cooked subsamples were presented in random order to each panellist. The LTL samples were evaluated for appearance (the consumer's first impression), colour (associated with consumer evaluation of meat quality), flavour, juiciness (liquid perceived during mastication), toughness (force needed to chew), and stringiness (fibre perceived during mastication) on a scale of 1 to 9 (AMSA, 2015).

Data of carcass weight, dressing, linear dimensions and compactness indices, meat characteristics, chemical composition and fatty acid profile were analysed in a completely random design using GLM procedure (SAS, 2002). The Tukey's multiple comparison of means test was used. Additionally, orthogonal polynomial coefficients were used to test the linear or quadratic effects of feeding PL on measured parameters. Categorical data such as conformation, fat degree, kidney fat cover and sensory evaluation were analysed with the nonparametric Kruskal-Wallis test. A probability of less than or equal to 0.05 ( $P$ $<0.05)$ was considered significant.

\section{Results}

Carcass shrinkage loss decreased linearly as $P L$ inclusion level increased in the diet $(P<0.01)$. In contrast, conformation and fat score increased linearly $(P<0.05)$ as dietary inclusion of $P L$ in the diet increased (Table 1). Neither carcass linear measurements nor carcass compactness indices were affected by diets. Only buttock perimeter was larger in lambs fed PL500 and PL250 diets $(P<0.05)$, compared with lambs fed PL0. Non-carcass components, offal, and digestive tract were similar in all treatments (Table 2).

Meat chemical composition was similar among treatments for moisture, ash, crude protein and ether extract (Table 3). No differences were observed among treatments in compression value. However, $\mathrm{pH}$ value increased linearly $(P<0.01)$ as the proportion of mesquite pods increased in the diet. In terms of colour, PL0 fed lamb LTL muscle was lighter and yellower than that of animals fed PL250 and PL500 diets $(P<0.01)$. Redness did not differ among meat samples from animals of the three treatments. No differences were noted in sensorial characteristics (Table 3). Overall, the sensory analysis data showed no adverse effect on the organoleptic properties of meat samples.

The major fatty acids in LTL lipids (Table 4) were the SFA palmitic (16:0; $28 \%$ of total FAME) and stearic (18:0; 17\%), MUFA oleic acid (18:1c9; 40\%) and PUFA linoleic acid (18:2n-6; 4\%). The PL0 diet increased $(P<0.05)$ the percentages of certain SF's (C15:0; C17:0), MUFA (C16:1:C17:1) and PUFA (C18:2n 6c), as well as total UFA, total PUFA $n-6$ and UFA/SFA and PUFA/SFA ratios. Meat of lambs fed PL250 had higher $(P<0.05)$ percentages of stearic $(C 18: 0, S F A)$ and elaidic acid $(C 18: 1 n 9 c$, MUFA $)$, total SFA and total TFA, while PL500 produced more oleic acid (C18:1n9c, MUFA).

\section{Discussion}

In a previous study using mesquite pods, Mahgoub et al. (2005a; 2006b) reported lower values for carcass weight and dressing than those of the current results. Recently, Negrete et al. (2016) observed in finishing lambs that addition of $300 \mathrm{~g}$ PL pods per $\mathrm{kg}$ DM improved carcass yield and classification and shrinkage loss. The reduction of shrinkage loss by mesquite pods could be related with the improvement of fat score. Savell et al. (2005) indicated that increased fatness might decrease shrinkage by serving as a barrier against moisture loss, or it might act to minimize the total moisture content in the carcass. These results strongly suggest that diets with PL pods have potential value in ruminant nutrition, since the quality of the resulting carcasses is comparable with that of carcasses of lambs fed conventional diets. 
Table 1 Means of carcass characteristics of Rambouillet lambs fed diets containing mesquite pods

\begin{tabular}{|c|c|c|c|c|c|c|}
\hline & \multicolumn{3}{|c|}{$\mathrm{PL}, \mathrm{g} / \mathrm{kg} \mathrm{DM}^{1}$} & \multirow[b]{2}{*}{$\mathrm{SEM}^{2}$} & \multicolumn{2}{|c|}{$p$-values } \\
\hline & PLPO & PLP250 & PLP500 & & Linear & Quadratic \\
\hline \multicolumn{7}{|l|}{ Growth performance } \\
\hline Initial bodyweight, kg & 23.3 & 21.6 & 22.8 & 4.16 & 0.79 & 0.44 \\
\hline Final bodyweight, kg & 37.7 & 39.1 & 41.1 & 6.34 & 0.33 & 0.93 \\
\hline Hot carcass weight, $\mathrm{kg}$ & 18.1 & 18.4 & 19.1 & 3.58 & 0.97 & 0.77 \\
\hline Cold carcass weight (CCW), kg & 17.0 & 17.7 & 18.3 & 3.33 & 0.84 & 0.91 \\
\hline Hot carcass dressing, \% & 48.0 & 47.0 & 46.5 & 2.42 & 0.11 & 0.09 \\
\hline Cold carcass dressing, $\%$ & 45.0 & 45.5 & 44.5 & 2.60 & 0.14 & 0.78 \\
\hline Carcass shrinkage loss, $\%$ & $6.3^{\mathrm{a}}$ & $5.3^{b}$ & $4.3^{\mathrm{c}}$ & 0.71 & 0.04 & 0.01 \\
\hline Conformation, EUROP ${ }^{3}$ & $7.0^{\mathrm{c}}$ & $8.4^{\mathrm{b}}$ & $11.1^{\mathrm{a}}$ & 1.20 & 0.003 & 0.04 \\
\hline Fat score, EUROP ${ }^{4}$ & $1.8^{\mathrm{c}}$ & $2.7^{\mathrm{b}}$ & $3.3^{\mathrm{a}}$ & 0.18 & 0.002 & 0.70 \\
\hline Kidney fat cover ${ }^{5}$ & 2.2 & 2.1 & 2.0 & 0.59 & 0.15 & 0.89 \\
\hline \multicolumn{7}{|l|}{ Carcass linear dimensions } \\
\hline Subcutaneous fat thickness, $\mathrm{mm}$ & 0.41 & 0.40 & 0.37 & 0.21 & 0.62 & 0.48 \\
\hline Buttock perimeter (B), cm & $41.0^{\mathrm{b}}$ & $42.6^{\mathrm{a}}$ & $43.1^{\mathrm{a}}$ & 3.02 & 0.02 & 0.29 \\
\hline Internal carcass length $(\mathrm{L}), \mathrm{cm}$ & 65.3 & 65.3 & 63.4 & 4.88 & 0.99 & 0.98 \\
\hline Hind limb length $(F), c m$ & 29.8 & 32.2 & 31.0 & 3.76 & 0.58 & 0.32 \\
\hline Buttock width (G), cm & 26.8 & 30.9 & 28.0 & 4.37 & 0.63 & 0.10 \\
\hline Thorax depth (Th), cm & 20.1 & 21.3 & 21.1 & 1.45 & 0.17 & 0.31 \\
\hline Thorax width $(\mathrm{Wr}), \mathrm{cm}$ & 27.4 & 28.5 & 28.0 & 5.19 & 0.83 & 0.72 \\
\hline \multicolumn{7}{|l|}{ Carcass compactness indices ${ }^{5}$} \\
\hline$L / G$ & 1.5 & 1.4 & 1.6 & 0.25 & 0.38 & 0.23 \\
\hline $\mathrm{Th} / \mathrm{G}$ & 0.76 & 0.69 & 0.78 & 0.12 & 0.75 & 0.20 \\
\hline $\mathrm{CCW} / \mathrm{L}, \mathrm{g} / \mathrm{cm}$ & 0.44 & 0.40 & 0.41 & 0.08 & 0.45 & 0.53 \\
\hline $\mathrm{G} / \mathrm{F}$ & 0.92 & 0.96 & 0.91 & 0.19 & 0.88 & 0.62 \\
\hline $\mathrm{Wr} / \mathrm{Th}$ & 1.4 & 1.3 & 1.3 & 0.31 & 0.75 & 0.93 \\
\hline Th/L & 0.51 & 0.50 & 0.49 & 0.05 & 0.38 & 0.88 \\
\hline
\end{tabular}

${ }^{1} \mathrm{PL}:$ Prosopis laevigata pods

${ }^{2}$ SEM: standard error of mean

${ }^{3}$ Conformation score on a 15-point scale where $1=$ poor and $15=$ excellent

${ }^{4}$ Fat score on a 5 -point scale where $1=$ very lean and $5=$ very fatty

${ }^{5}$ Kidney fat cover on a scale 3 -point scale where $1=$ poor and $3=$ abundant

${ }^{5}$ Internal carcass length $(\mathrm{L})$, hind limb length $(\mathrm{F})$, buttock perimeter (B), buttock width $(\mathrm{G})$, thorax depth (Th) and thorax width (Wr), cold carcass weight (CCW)

${ }^{a-b}$ Row means with different superscripts differ at $P<0.05$

Conformation and fat scores were influenced by treatments with PLP. Similarly, Negrete et al. (2016) found that lambs fed $300 \mathrm{~g} \mathrm{PLP} / \mathrm{kg}$ had better conformation than lambs not fed PLP. Mesquite in diets decreased the acetate : propionate ratio in the rumen, owing to increases in propionate (Peña-Avelino et al., 2016), which is a precursor of glucose, the main carbon source for deposition of fat tissue. This change may have promoted the higher degree of fat on carcasses of lambs fed mesquite diets.

The only difference in carcass linear dimensions was buttock perimeter (B), which was larger in lambs fed mesquite diets than in PLO fed lambs. This can be correlated with fat and conformation scores, which were also higher in mesquite-fed animals. Non-carcass components did not differ among treatments. These results were within the range of acceptable values (Obeidat et al., 2008). Dietary treatments were formulated with the same content of neutral detergent fibre, but there were more non-structural carbohydrates in PL 
diets, and that may have influenced the palatability of the PL500 diet, promoting higher intake, although it did not influence the weight of the digestive tract.

Table 2 Means of non-carcass components of Rambouillet lambs fed diets containing mesquite pods

\begin{tabular}{|c|c|c|c|c|c|c|}
\hline & \multicolumn{3}{|c|}{$\mathrm{PL}, \mathrm{g} / \mathrm{kg} \mathrm{DM}^{1}$} & \multirow[b]{2}{*}{ SEM $^{2}$} & \multicolumn{2}{|c|}{$p$-values } \\
\hline & PLO & PL250 & PL500 & & Linear & Quadratic \\
\hline \multicolumn{7}{|l|}{ Non-carcass components } \\
\hline Heart weight, $\mathrm{kg}$ & 0.25 & 0.22 & 0.25 & 0.07 & 0.97 & 0.35 \\
\hline Liver weight, kg & 0.78 & 0.72 & 0.75 & 0.15 & 0.71 & 0.44 \\
\hline Spleen weight, kg & 0.06 & 0.04 & 0.05 & 0.02 & 0.72 & 0.17 \\
\hline Kidney weight, kg & 0.31 & 0.24 & 0.25 & 0.10 & 0.21 & 0.34 \\
\hline Testes weight, $\mathrm{kg}$ & 0.16 & 0.16 & 0.26 & 0.10 & 0.99 & 0.17 \\
\hline Lungs and trachea, $\mathrm{kg}$ & 0.71 & 0.68 & 0.73 & 0.19 & 0.86 & 0.63 \\
\hline \multicolumn{7}{|l|}{ Digestive tract } \\
\hline Rumen, empty, kg & 1.5 & 1.6 & 1.7 & 0.22 & 0.06 & 0.09 \\
\hline Rumen content, kg & 4.6 & 5.3 & 5.5 & 0.94 & 0.13 & 0.57 \\
\hline Small intestine, empty, kg & 0.79 & 0.77 & 0.84 & 0.16 & 0.59 & 0.56 \\
\hline Small intestine content, $\mathrm{kg}$ & 0.38 & 0.57 & 0.52 & 0.20 & 0.27 & 0.26 \\
\hline Large intestine, empty, kg & 0.98 & 0.95 & 0.93 & 0.19 & 0.59 & 0.95 \\
\hline Large intestine content, $\mathrm{kg}$ & 0.61 & 0.52 & 0.82 & 0.11 & 0.33 & 0.30 \\
\hline \multicolumn{7}{|l|}{ Offal } \\
\hline Skin, kg & 4.5 & 4.2 & 4.7 & 0.84 & 0.70 & 0.27 \\
\hline Blood, kg & 1.6 & 1.6 & 1.6 & 0.23 & 0.99 & 0.35 \\
\hline Horned head, kg & 2.0 & 2.0 & 1.9 & 0.26 & 0.78 & 0.72 \\
\hline Feet, kg & 1.2 & 1.2 & 1.1 & 0.17 & 0.39 & 0.89 \\
\hline
\end{tabular}

PL: Prosopis laevigata pods

${ }^{2}$ SEM: standard error of the mean

${ }^{\mathrm{a}-\mathrm{b}}$ Row means with different superscripts differ at $P<0.05$

Chemical composition in LTL was in agreement with Komprda et al. (2012), who studied growing lambs. The pH observed in meat was similar to that reported by Obeidat et al. (2011) using mesquite diets. The normal pH range in lamb meat is about 5.4 to 5.6 (Young et al., 2004), and even 5.8 (Safari et al., 2011). This result shows that $\mathrm{pH}$ is within standard reference values. The indicators of colour values $(\mathrm{L}, \mathrm{a}$ and $\mathrm{b})$ in lambs fed PL were different from those reported by Obeidat et al. (2008) in sheep fed a $200 \mathrm{~g} / \mathrm{kg}$ Prosopis juliflora diet. This may be related to low levels of secondary compounds such as tannins, which produce lighter-coloured meat, as found by Negrete et al. (2016). The differences in coloration between the control diet and PL treatments can be associated with ultimate $\mathrm{pH}$. In other species, when $\mathrm{pH}$ is low, the meat is pale (Gajana et al., 2013). The results indicated that the $L$ value of meat from PL0-fed lambs was higher than that from lambs fed mesquite diets, while $b$ was higher in meat from PL0-fed animals.

Meat sensory attributes are important because they reflect meat quality and consumer preferences (Rodrigues \& Teixeira, 2009). Little is known about the sensorial changes produced by mesquite diets. In the current study, the authors found no significant effect on sensorial characteristics. The meat produced by mesquite had good acceptance by panellists, indicating no adverse effects on attributes of sensory meat quality. Factors such as feed ingredients, animal handling, and slaughtering procedures have important effects on the attribute texture that involves juiciness, tenderness, pastiness, adhesion to teeth and stringiness. Flavour can be associated with the reserves of fat and fatty acid profile (Jeremiah et al., 1998), but the authors found no differences in lamb flavour among samples in the current study, in agreement with Miranda-de la Lama et al. (2012). 
Table 3 Means of chemical composition and sensory characteristics of Longissimus thoracis et lumborum muscle from lambs fed finishing diets containing mesquite pods

\begin{tabular}{|c|c|c|c|c|c|c|}
\hline & \multicolumn{3}{|c|}{$\mathrm{PL}, \mathrm{g} / \mathrm{kg} \mathrm{DM}^{1}$} & \multirow[b]{2}{*}{$\mathrm{SEM}^{2}$} & \multicolumn{2}{|c|}{$p$-values } \\
\hline & PLO & PL250 & PL500 & & Linear & Quadratic \\
\hline \multicolumn{7}{|l|}{ Chemical composition } \\
\hline Moisture, $\mathrm{g} / 100 \mathrm{~g}$ meat & 70.7 & 72.1 & 71.1 & 1.18 & 0.56 & 0.04 \\
\hline Ash, g/100g meat & 1.1 & 1.0 & 1.1 & 0.11 & 0.23 & 0.19 \\
\hline Crude protein, $\mathrm{g} / 100 \mathrm{~g}$ meat & 21.9 & 21.8 & 21.6 & 1.40 & 0.09 & 0.03 \\
\hline Ether extract, $\mathrm{g} / 100 \mathrm{~g}$ meat & 4.1 & 3.6 & 3.8 & 0.87 & 0.58 & 0.35 \\
\hline $\mathrm{pH}(24 \mathrm{~h}$ post mortem) & $5.5^{\mathrm{b}}$ & $5.7^{\mathrm{a}}$ & $5.8^{\mathrm{a}}$ & 0.12 & 0.001 & 0.50 \\
\hline Compression, $\mathrm{kg}$ & 1.4 & 1.6 & 1.6 & 0.41 & 0.09 & 0.62 \\
\hline \multicolumn{7}{|l|}{ Meat colour } \\
\hline L (lightness) & $45.8^{\mathrm{a}}$ & $42.4^{\mathrm{b}}$ & $42.5^{\mathrm{b}}$ & 3.11 & 0.002 & 0.19 \\
\hline $\mathrm{a}$ (redness) & 9.2 & 9.9 & 9.7 & 1.20 & 0.07 & 0.79 \\
\hline b (yellowness) & $14.7^{\mathrm{a}}$ & $13.4^{\mathrm{b}}$ & $13.5^{\mathrm{b}}$ & 1.21 & 0.06 & 0.007 \\
\hline \multicolumn{7}{|l|}{ Sensory analysis ${ }^{3}$} \\
\hline Appearance $^{4}$ & 5.4 & 6.0 & 5.8 & 0.28 & 0.54 & 0.25 \\
\hline Colour ${ }^{5}$ & 6.5 & 6.8 & 6.6 & 0.25 & 0.70 & 0.07 \\
\hline Flavour $^{6}$ & 6.7 & 7.0 & 6.6 & 0.19 & 0.39 & 0.59 \\
\hline Juiciness $^{7}$ & 6.4 & 6.4 & 6.0 & 0.24 & 0.94 & 0.12 \\
\hline Toughness $^{7}$ & 6.8 & 6.5 & 6.5 & 0.18 & 0.36 & 0.23 \\
\hline Stringiness ${ }^{8}$ & 6.8 & 7.1 & 7.1 & 0.23 & 0.22 & 0.11 \\
\hline
\end{tabular}

TL: Prosopis laevigata pods

${ }^{2}$ SEM: standard error of the mean

${ }^{3}$ Sensory analysis on a 9-point scale

${ }^{4}$ Appearance ranging from $1=$ dislike very much to $9=$ like very much

${ }^{5}$ Colour ranging from $1=$ very dark, to $9=$ very light

${ }_{7}^{6}$ Flavour, ranging from 1 = extremely intense to $9=$ not perceptible

${ }^{7}$ Juiciness and toughness ranging from 1 = very dry, $9=$ extremely juicy

${ }^{8}$ Stringiness ranging from $1=$ very high to $9=$ very low

${ }^{a-b}$ Row means with different superscripts differ at $P<0.05$

The results showed that the PLO diet resulted in higher concentrations of most SFA, UFA and PUFA n-6 compared with PL250 and PL500 diets. It may be explained by the fatty acid profile of mesquite pods. Indeed, Negrete et al. (2016) indicated that C16:0, C18:0, C18:1 and C18:2 account for more than 90\% of total FA, indicating that mesquite pods have 1.6-fold more C16:0, 4.3-fold more C18:0, 0.3-fold less C18:1 and 0.4 -fold less C18:2 than maize grain, which was the conventional grain that was replaced in greater proportion when mesquite pods were included in the experimental diets. The ratio PUFA n6/n3 did not differ among treatments. Regardless of treatment, the $n 6 / n 3$ ratio in meat surpassed the recommended value, but PL500 had the lowest value. Luciano et al. (2013) observed an n6/n3 ratio of 3.47 with pasture diet, intermediate values of 5.30-10.85 with pro-oxidants, and 11.72 with feed concentrates. 
Table 4 Fatty acid composition ( $\mathrm{g} / 100 \mathrm{~g}$ total fatty acid) of Longissimus thoracis et lumborum from lambs fed finishing diets containing mesquite pods

\begin{tabular}{|c|c|c|c|c|c|c|}
\hline & & g/kg D & & & & lues \\
\hline & PLO & PL250 & PL500 & $\mathrm{SEM}^{2}$ & Linear & Quadratic \\
\hline C10:0 & 0.21 & 0.24 & 0.22 & 0.04 & 0.48 & 0.77 \\
\hline C12:0 & 0.23 & 0.24 & 0.23 & 0.06 & 0.91 & 0.49 \\
\hline C14:0 & 3.8 & 3.7 & 3.6 & 0.49 & 0.35 & 0.84 \\
\hline C15:0 & $0.52^{\mathrm{a}}$ & $0.48^{\mathrm{a}}$ & $0.34^{\mathrm{b}}$ & 0.09 & 0.002 & 0.28 \\
\hline C16:0 & 27.9 & 28.0 & 28.2 & 1.3 & 0.50 & 0.96 \\
\hline C16:1 & $2.8^{\mathrm{a}}$ & $2.6^{\mathrm{b}}$ & $2.6^{\mathrm{b}}$ & 0.21 & 0.03 & 0.12 \\
\hline C17:0 & $1.5^{\mathrm{a}}$ & $1.4^{\mathrm{ab}}$ & $1.2^{b}$ & 0.20 & 0.003 & 0.44 \\
\hline C17:1 c9 & $1.02^{\mathrm{a}}$ & $0.74^{\mathrm{b}}$ & $0.66^{\mathrm{b}}$ & 0.14 & 0.007 & 0.27 \\
\hline C18:0 & $14.5^{\mathrm{b}}$ & $17.1^{\mathrm{a}}$ & $16.5^{\mathrm{a}}$ & 1.35 & 0.02 & 0.02 \\
\hline C18:1 t9 & $2.5^{\mathrm{ab}}$ & $2.9^{\mathrm{a}}$ & $1.7^{\mathrm{b}}$ & 0.64 & 0.04 & 0.02 \\
\hline C18:1 c9 & $39.0^{\mathrm{ab}}$ & $37.9^{b}$ & $40.9^{\mathrm{a}}$ & 1.8 & 0.07 & 0.03 \\
\hline C18:2 n-6 (LA) & $4.5^{\mathrm{a}}$ & $3.4^{\mathrm{ab}}$ & $2.5 b$ & 1.3 & 0.009 & 0.85 \\
\hline C18:3 n-3 (ALA) & 0.51 & 0.34 & 0.31 & 0.15 & 0.15 & 0.16 \\
\hline C18:2 CLA cis9-trans11 & 0.51 & 0.48 & 0.50 & 0.10 & 0.95 & 0.55 \\
\hline C20:4 n-6 (AA) & 0.50 & 0.48 & 0.54 & 0.11 & 0.52 & 0.41 \\
\hline Total SFA ${ }^{3}$ & $48.7^{\mathrm{b}}$ & $51.2^{\mathrm{a}}$ & $50.3^{\mathrm{ab}}$ & 1.7 & 0.10 & 0.04 \\
\hline Total UFA ${ }^{4}$ & $51.3^{\mathrm{a}}$ & $48.8^{\mathrm{b}}$ & $49.7^{\mathrm{ab}}$ & 1.6 & 0.09 & 0.03 \\
\hline Total MUFA ${ }^{5}$ & 45.3 & 44.1 & 45.9 & 1.4 & 0.49 & 0.04 \\
\hline Total PUFA-n $6^{6}$ & $5.0^{\mathrm{a}}$ & $3.9^{\mathrm{ab}}$ & $3.0^{\mathrm{b}}$ & 1.3 & 0.01 & 0.79 \\
\hline Total trans $^{7}$ & $3.0^{\mathrm{ab}}$ & $3.4^{\mathrm{a}}$ & $2.2^{\mathrm{b}}$ & 0.66 & 0.04 & 0.02 \\
\hline$n 6 / n 3$ ratio & 9.8 & 11.4 & 9.8 & 3.8 & 0.36 & 0.08 \\
\hline UFA/SFA & $1.1^{\mathrm{a}}$ & $0.95^{\mathrm{ab}}$ & $0.99^{b}$ & 0.07 & 0.09 & 0.05 \\
\hline PUFA/SFA & $0.11^{\mathrm{a}}$ & $0.08^{\mathrm{ab}}$ & $0.07^{\mathrm{b}}$ & 0.03 & 0.02 & 0.55 \\
\hline
\end{tabular}

'PL: Prosopis laevigata pods

${ }^{2}$ SEM: standard error of mean

${ }^{3}$ SFA (saturated fatty acid): $\sum(\mathrm{C} 10: 0 ; \mathrm{C12}: 0 ; \mathrm{C14}: 0 ; \mathrm{C15}: 0 ; \mathrm{C16}: 0 ; \mathrm{C} 17: 0 ; \mathrm{C18:0})$

${ }^{4} U F A$ (unsaturated fatty acid): $\Sigma(\mathrm{C} 16: 1 ; \mathrm{C} 17: 1$; C18:1t9, C18:1c9, C18:2 n-6, C18:3 n-3, C18, C18 :2 CLA cis9-trans11), C20:4 n-6

${ }^{5}$ MUFA (monounsaturated fatty acid) $: \sum(\mathrm{C} 16: 1 ; \mathrm{C} 17: 1 ; \mathrm{C} 18: 1 \mathrm{n} 9 \mathrm{t} ; \mathrm{C} 18: 1 \mathrm{n} 9 \mathrm{c})$

${ }^{6}$ PUFA (polyunsaturated fatty acid)

${ }^{6}$ PUFA-n6: $\sum$ (C18:2n6c C20:4 n-6) TFA: $\sum($ C18:1n9t; CLA cis9-trans11).

${ }^{\mathrm{a}-\mathrm{b}}$ Row means with different superscripts differ at $P<0.05$

\section{Conclusion}

This study showed that high levels of mesquite pods do not have an adverse effect on carcass dressing and weight, carcass linear dimensions, carcass compactness indices and non-carcass components. Neither compression value nor chemical of meat was affected by mesquite pods. Even more, mesquite pods reduced carcass shrinkage loss, and improved muscle conformation and degree of fat. Mesquite pods increased percentages of total TFA and SFA, and therefore reduced percentages of most unsaturated and polyunsaturated fatty acid n- 6 in meat lamb. The consumer panel could not differentiate between meat appearance, colour, flavour, juiciness, toughness and stringiness from lambs fed mesquite diets and those produced with the control diet. Mesquite pods are a non-conventional ingredient with potential value as a cheap alternative for livestock feedstuff in arid and semi-arid areas. 


\section{Authors' Contributions}

LPA: doctoral student who conducted the experiment; JPR: mentor, conception and design; JCGL \& JV; carcass evaluation; AGL: meat analysis; and LYE: fatty acid and sensory analysis.

\section{Conflict of Interest Declaration}

The authors have declared that no competing interests exist.

\section{References}

AMSA, 2015. Research guidelines for cookery, sensory evaluation and instrumental tenderness measurements of fresh meat. (2nd ed.) American Meat Science Association in Cooperation with National Livestock and Meat Board. Chicago, IL., USA.

AOAC, 2006. Official methods of analysis. (18th ed.). Association of Official Analitycal Chemists, Inc., Washington DC, USA.

Camfield, P., Brown, A., Lewis, P., Rakes, L. \& Johnson, Z., 1997. Effects of frame size and time-on-feed on carcass characteristics, sensory attributes, and fatty acid profiles of steers. J. Anim. Sci. 75, 1837-1844.

Colomer-Rocher, F., Delfa, R. \& Sierra, A.I., 1988. I. Método normalizado para el estudio de los caracteres cuantitativos de las canales, según los sistemas de producción. In: Métodos Normalizados para el Estudio de Caracteres Cuantitativos e Cualitativos de las Canales Ovinas y Caprinas. Cuad: Instituto Nacional de Investigaciones Agrarias. 17, 19-41 (in Spanish).

EEC Regulation. 1994. Council Regulation (EC) No 1278/94 of 30 May 1994 amending Regulation (EEC) No 338/91 determining the community standard quality of fresh or chilled sheep carcasses and Regulation (ECC) No $2137 / 92$ concerning the community scale for the classification of carcasses of ovine animals and determining the community standard quality of fresh or chilled sheep carcasses. Official Journal L 140 of 03-06-1994.

Folch, J., Lees, M. \& Sloane-Stanley, G.H., 1957. A simple method for the isolation and purification of total lipids from animal tissues. J. Biol. Chem. 226, 497-509.

Gajana, C.S., Nkukwana, T.T., Marume, U. \& Muchenje, V., 2013. Effects of transportation time, distance, stocking density, temperature and lairage time on incidences of pale soft exudative (PSE) and the physico-chemical characteristics of pork. Meat Sci. 95, 520-525.

Gómez-Brandón, M., Lores, M. \& Domínguez, J., 2008. Comparison of extraction and derivatization methods for fatty acid analysis in solid environmental matrixes. Anal. Bioanal. Chem. 392, 505-514.

Jeremiah, L.E., Tong, A.K.W. \& Gibson, L.L., 1998. The influence of lamb chronological age, slaughter weight and gender. Flavour and texture profiles. Food Res. Int. 31, 227-242.

Komprda, T., Kuchtik, J., Jarosova, A., Drackova, E., Zemanek, L. \& Filipcik, B., 2012. Meat quality characteristics of lambs of three organically raised breeds. Meat Sci. 91, 499-505.

Luciano, G., Biondi, L., Scerra, M., Serra, A., Mele, M., Lanza, M. \& Priolo, A., 2013. The effect of the change from a herbage- to a concentrate-based diet on the oxidative stability of raw and cooked lamb meat. Meat Sci. 95, 212218.

Mahgoub, O., Kadim, I.T., Forsberg, N.E., Al-Ajmi, D.S., Al-Saqry, N.M., Al-Abri, A.S. \& Annamalai, K., 2005a. Evaluation of Meskit (Prosopis juliflora) pods as a feed for goats. Anim. Feed Sci. Technol. 121, 319-327.

Mahgoub, O., Kadim, I.T., Johnson, E.H., Srikandakumar, A., Al-Saqri, N.M., Al-Abri, A.S. \& Ritchie, A., 2005b. The use of a concentrate containing Meskit (Prosopis juliflora) pods and date palm by-products to replace commercial concentrate in diets of Omani sheep. Anim. Feed Sci. Technol. 120, 33-41.

Miranda-de la Lama, G.C., Villarroel, M., del Mar Campo, M., Olleta, J.L., Sañudo, C. \& María, G.A., 2012. Effects of double transport and season on sensorial aspects of lamb's meat quality in dry climates. Trop. Anim. Health Prod. 44, 21-27.

Negrete, L.O., Pinos-Rodríguez, J.M., Grajales-Lagunes, A., Morales, J.A., García-López, J.C. \& Lee-Rangel, H.A., 2016. Effects of increasing amount of dietary Prosopis laevigata pods on performance, meat quality and fatty acid profile in growing lambs. J. Anim. Physiol. Anim. Nutr. doi:10.1111/jpn.12606.

NOM-033-SAG/ZOO-2014, Norma Oficial Mexicana, Métodos para dar muerte a los animales domésticos y silvestres. Diario Oficial de la Federación. Augost 28th 2015. México (in Spanish).

Obeidat, B.S., Abdullah, A.Y. \& Al-Lataifeh, F.A., 2008. The effect of partial replacement of barley grains by Prosopis juliflora pods on growth performance, nutrient intake, digestibility, and carcass characteristics of Awassi lambs fed finishing diets. Anim. Feed. Sci. Technol. 146, 42-54.

Obeidat, B.S., Alrababah, M.A., Abdullah, A.Y., Alhamad, M.N., Gharaibeh, M.A., Rababah, T.M. \& Abu Ishmais, M.A., 2011. Growth performance and carcass characteristics of Awassi lambs fed diets containing carob pods (Ceratonia siliqua L.). Small Rum. Res. 96, 149-154.

Peña-Avelino, L.Y., Pinos-Rodríguez, J.M., Juárez-Flores, B.I. \& Yáñez-Estrada, L., 2016. Effects of Prosopis laevigada pods on growth performance, ruminal fermentation and blood metabolites in finishing lambs. S. Afr. J. Anim. Sci. 46, 360-365.

Peña-Avelino, L.Y., Pinos-Rodríguez, J.M., Yañez-Estrada, L., Juárez-Flores, B.I., Mejia, R. \& Andrade-Zaldivar, H., 2014. Chemical composition and in vitro degradation of red and white mesquite (Prosopis laevigata) pods. S. Afr. J. Anim. Sci. 44, 298-306.

Rodrigues, S. \& Teixeira, A., 2009. Effect of sex and carcass weight on sensory quality of goat meat of Cabrito Transmontano. J. Anim. Sci. 87, 711-715.

Ruiz de Huidobro, F., Miguel, E., Cañeque, V. \& Velasco, S., 2005. Conformación, engrasamiento y sistemas de clasificación de la canal ovina. In: Estandarización las metodologias para evaluar la calidad del producto (animal 
vivo, canal, carne y grasa) en los rumiantes; Cañeque, V., Sañudo, C. (eds). Monografías. INIA: serie ganadera 3, 143-178. Madrid, España (in spanish).

Safari, J.G., Mushi, D.E., Mtenga, L.A., Kifaro, G.C. \& Eik, L.O., 2011. Growth, carcass yield and meat quality attributes of Red Maasai sheep fed wheat straw-based diets. Trop. Anim. Health Prod. 43, 89-97.

SAS, Statistical Analysis System. 2002. SAS/STAT 9 User's Guide. Carry, NC, USA: SAS Institute Inc.

Savell, J.W., Mueller, S.L. \& Baird, B.E., 2005. Chilling of carcasses. Meat Sci. 70, 449-459.

Sawal, R.K., Ram Ratan \& Yadav, S.B.S., 2004. Mesquite (Prosopis juliflora) pods as a feed resource for livestock -A Review-. Asian-Aust. J. Anim. Sci. 17, 719-725.

Young, O.A., West, J., Hart, A.L. \& van Otterdijk, F.F.H., 2004. A method for early determination of meat ultimate $\mathrm{pH}$. Meat Sci. 66, 493-498.

Zimerman, M., Domingo, E. \& Lanari, M.R., 2008. Carcass characteristics of Neuquén Criollo kids in Patagonia region, Argentina. Meat Sci. 79, 453-457. 